\title{
CONCEPTS OF RURALITY AND URBANITY AS ANALYTICAL CATEGORIES IN MULTIDIMENSIONAL RESEARCH
}

\author{
Laila Kūle \\ Faculty of Geography and Earth Sciences, University of Latvia, Raiṇa bulv. 19, Rīga LV-1586, LATVIA \\ E-mail: laila.kule@lu.Iv
}

Communicated by O!̣gerts Nikodemus

\begin{abstract}
This paper is a review of the concepts of rurality and urbanity and of various approaches to their differentiation. The author reviews the continuum and dichotomy of rurality and urbanity and the challenges that occur when seeking to differentiate between them. The author has reviewed the descriptive approach, which is based on empirical data, as well as the social approach, which is based on various social agents and different ways of perceiving space. The author has evaluated various approaches to studying rural-urban separation, focusing on the challenges that are created by contemporary developments in society. New forms of populated areas are emerging, and they do not correspond to this binary separation. Both rural and urban areas are becoming increasingly multidimensional and interactions between them more intensive. "Urban" and "rural" are abstractions and metaphors that are needed to ensure human communications which enables the bridging of knowledge from one area of science or politics to another. That is particularly relevant for interdisciplinary research such as spatial and environmental studies. In the conclusion, the author reviews the way in which rurality and urbanity are studied by researchers in Latvia.
\end{abstract}

Key words: rural, urban, nature-society, environment, Latvia.

\section{INTRODUCTION}

A study of how rurality and urbanity are understood is important in Latvia and in the broader context. Developments in society have promoted changes in the identity of countryside and towns. The local and regional government reforms occurring in Latvia and elsewhere in Europe encourage us to review the concepts of rurality and urbanity, so that we can see how important they are to local residents, government systems, and also researchers. The separation between rurality and urbanity has long been a principle of organising time and space, and researchers in various sectors have relied on this. Geographers, regional planners, sociologists, anthropologists, attorneys and economists have all invested in researching the concepts of urbanity and rurality. Researchers in the social and natural fields of study have used each other's theoretical concepts "to elucidate the complexity of the human context of the urban [and rural] ecosystem" (Simmons et al., 2002, pp. 5-6). Even more, researchers from other fields of study - biologists, environmental specialists, economists, representatives of the technological sciences-have used existing concepts to differentiate between urbanity and rurality in their own research, particularly in terms of extensive comparisons of various processes. The aim of this paper is to review the conceptual understanding of "urban" and "rural" and the different approaches in describing these. Insight is given into the vari- ous indicators used for describing the rural-urban differences, the efforts to overcome the dichotomies of the division between the rural and the urban and the ways how these concepts are socially constructed. In the conclusion, the author will review the way in which "rurality" and "urbanity" are reflected in research in Latvia based on the concepts discussed.

The search for an adequate definition of "urban" and "rural" and for the understanding of these categories was particularly active during the 20th century (Wirth, 1938; Halfacree, 1993). This long-lasting interest can be attributed to the fact that definitions of town and countryside and the drawing of the line between them has been more than just a scholarly matter. These are issues that are broadly addressed in normative and political documents dealing with spatial and social development, environmental protection, methods for promoting agricultural development and public services, etc. These are categories which are also used in everyday communication, in the mass media, and in the arts. The geographer Tuan has argued that researchers seek statistical measures that would define an ideal type of an urban place, or they search for the historical origins or primitive forms of populated areas to identify their true meaning with root meaning. It is futile, however, to seek a definition of a city which commands universal assent, Tuan argues, because cities differ in terms of their characteristics and the intensity 
of their urban lifestyle. They are monuments to material culture, and people who live there find themselves at varying distances from human conditions that are close to nature. This is seen in food production, the agricultural cycle, and the extent to which a city's rhythms differ from the natural rhythms of day and night and of the seasons (Tuan, 1978).

Even though determining the rural-urban gradient is a widely used method to study the effects of urbanisation on ecological systems and processes in landscapes and elements thereof, species and their behaviour, the environment and the level of pollution (McDonnell and Pickett, 1990; Hahs and McDonnell, 2006, p. 435). As a result, researchers and policy authors often reduce oversimplified humanmodified ecosystems to merely urban versus rural (Theobald, 2004), and these concepts take on the meaning of metaphors. Just as we can understand the nature of concepts exclusively from the perspective of human knowledge and how it is presented and represented (Harrison and Burgess, 1994), a more in-depth understanding of the concepts of "urban" and "rural" is possible only if we understand the relationship between space and the individual. Brown and Cromartie (2004) have proposed that the concept of "rural" include ecological, economic, institutional, social and cultural dimensions and that its complex definition cover not just territories, but also the typical characteristics of the residents of these territories. We can now turn to a more in-depth review of different approaches toward the concept of urbanity and rurality.

\section{DICHOTOMY BETWEEN THE CONCEPTS OF UR- BANITY AND RURALITY}

"Urban" and "rural" as a separation in binary perception have created conventional, administrative, imaginative and intellectual boundaries (Cloke and Johnston, 2005, p. 10) in terms of a unified perception of geographic space. A binary worldview was used in 1887 by the German scholar Tonnies, who produced what is now a classical monograph in sociology, Gemeinschaft und Gesellschaft. He accepted rural areas as communities and towns and cities as spaces where the civil society could manifest itself, arguing that cities, unlike conservative rural areas, are an expression of modernity and capitalism (Claval, 2007, p. 154). There have been attempts to dispute this traditional dualism (Pahl, 1966; Lacour and Puissant, 2007), but research, policies and everyday lives are still based on it, because the difference "goes beyond the material look of the land and implies more deep-seated differences born of separation from and an attachment to the nature of the physical environment" (Cloke and Johnston, 2005, p. 10). The extreme levels of the contrast in the rurality-urbanity continuum have been noted, and they have usually been defined with acceptable precision, but the same cannot be said of the part of the continuum which lies between these two extremes (Thorns, 2002 , p. 25). There is no concrete border where urbanity disappears and rurality begins, and the division between urban and rural is necessarily arbitrary. The boundaries of ur- ban agglomerations seldom coincide with administrative borders, which makes the use of certain statistical indicators rather questionable (Tjallingii, 2000).

Urbanity and rurality are ideal models, abstractions or simplifications of the real world. This is based on the assumption that there are fundamental differences between people who live in cities or towns and those who live in the countryside or the populated territories thereof. The assumption is based on stereotypes that are broadly used by researchers, and particularly by government institutions and societies throughout the world. Stereotypic ideas about urban and rural areas are multidimensional and include claims about the physical environment, the level of construction, accessibility, resources, the nature, scope and costs of economic activities, autonomy and governance, innovations, the quality of life, contacts among individuals, values and opportunities (Wirth, 1938; Mann, 1965; Pahl, 1966; Hugo et al., 2003; Brown and Cromartie, 2004; Tilt et al., 2007).

\section{INDICATORS CHARACTERISING THE DIFFERENCE BETWEEN URBANITY AND RURALITY}

The crude rural-urban ratio indicator which is used in environmental and developmental research has been extensively criticised (Richardson, 2000; Tjallingii, 2000; Coombes and Raybould, 2001; Hugo et al., 2003). As there is no single indicator that can be used to characterise a populated area, there is a series of indicators used to describe the multidimensional rural-urban split. It has been argued that a study of a populated area must take into account both the location and its residents (Andranovich and Riposa, 1993), as well as the interaction between the two. When it comes to a territory, there are two approaches. The more commonly used approach is to apply indicators to administratively determined local government or community territories. The other, less commonly used, is to look at a built-up territory irrespective of its location or its administrative affiliation. Rural and urban territories can be characterised by indicators such as the use of land, the relative placement of the territory, and existing built-up areas. Residents of the two types of areas are characterised by indicators such as population density, the number of residents in a formally determined administrative territory or a specific and compact aggregate of urban residents, as well as descriptions of social groups (Pumain et al., 1992; Anonymous, 1994; Pfuderer, 2003).

Indicators of interaction between a territory and its residents can include types of employment, particularly looking at the proportion of those who are engaged in agriculture or the primary sector, the availability of necessary skills, economic development, including the level of services and the existence of links to the regional or central town of the relevant region. Other indicators include back-and-forth migration, the frequency and availability of public transportation services, the administrative status and historical name of the local government territory, the identity and indicators of the sense of place, the sense of community and the sense of iso- 
lation and naturalness, the number of abandoned plots of land and buildings, the level of quiet or the distance from a source of noise, the darkness of the sky at night, and the beauty of the surrounding landscape (Plowden, 1995; Cloke, 1999; Coombes and Raybould, 2001; Hill, 2003; Champion and Hugo, 2004; Bowler, 2005). These indicators can be applied not only towards identifying rural or urban territories, but also in terms of identifying the ideas of researchers and those who commission research as to ideal rurality or urbanity.

In ecological research, the urban-rural gradient is described via various indicators, which can be assembled in at least three basic groups: 1) demographic variables; 2) physical variables such as density of roads or buildings, the percentage of urban land cover, or the distance from the urban centre; and 3) landscape metrics such as the mean size or fractal dimension of patches of land. Researchers have noted that each of these offers a look into various aspects of the process of urbanisation, and they are not, therefore, mutually exclusive (Hahs and McDonnell, 2006, p. 435). Also, in order to describe the amount of human modification, ecologists use a transect of the urban area, and they also identify the subjective views of local residents.

Freely selected boundaries between "rural" and "urban" often fail to produce a true reflection of a specific location and of relevant processes in a specific period of time (Theobald, 2004). Thus, for example, population numbers are calculated on the basis of where people spend the night and are registered. Daily, weekly or seasonal back-and-forth migrants, people on vacation, people visiting summer homes, tourists, traditional and contemporary tramps and homeless people-these often appear in no population register. Populated areas and structures therein can be episodic, nonspecific, temporary, periodical, regularly temporary, seasonal, partly independent or entirely independent (Hill, 2003). Homes, places of employment and places where services are rendered may also be portable. This poses challenges that require a new and more open approach in analysing populated areas and differences among them.

\section{EFFORTS TO OVERCOME THE DICHOTOMOUS DI- VISION BETWEEN URBANITY AND RURALITY}

In disputing the binary division between urbanity and rurality as a static depiction of geographic space in time, a method that does not include social and spatial change, increasing numbers of researchers and policy authors are considering the interaction of rural and urban geographic spaces (Cloke and Park, 1985; Funnell, 1988; Lynch, 2004) as a process that can be influenced in terms of creating new forms of co-operation and developing these in a way that is favourable for the environment, the community and its economy (Jones, 2004).

In the overall system of populated areas, a city is the centre and the rural areas are the periphery. Between these two there is a wide variety of people, ideas and material values, and the flow of these can change, sometimes dominating and people and their activities in spatial and territorial terms may invoke greater concentration, but at other times involve deconcentration. Urbanity and rurality can be both a goal and a process, and these object and process-oriented discourses in ecological and regional development are not mutually exclusive. Indeed, there are benefits when they work together (Hidle et al., 2006). For a long time now there has been discourse, which sees town and country as expressions of the culture-nature polarity, where nature is perceived as an object, i.e., as territories or species that simply exist or do not exist. This discourse has encountered the emerging discourse of ecological modernisation, which is based on processes of nature (Tjallingii, 2000, p. 104).

As the automobilisation of society has progressed, information communication technologies have developed, and the infrastructural networks for those technologies have become available in rural areas, it has increasingly been argued that differences between rural and urban areas are disappearing, and the characteristics of the two types of areas are intermingling. Rural areas are undergoing urbanisation, while cities are undergoing ruralisation (their population densities are declining). Authors have argued that this is a gradual transition (Sorokin and Zimmerman, 1929, cited in Coke, 1979; Pahl, 1966; Bryant et al., 1982). Abrupt changes are possible if: 1) the boundaries are specified by natural factors such as bodies of water, wetlands or terrain; or 2) territorial or public activities are limited because of normative regulations related to aspects such as territorial planning or policies aimed at protecting culture or nature.

Changing constructions and representations of rurality and urbanity have emerged gradually, and researchers initially reacted simply by ignoring the challenges that were posed. They continued to engage in traditional research, e.g., ignoring the multifunctional nature of rurality. Later research about rurality was justified as a pragmatic spatial categorisation to counterbalance the intellectual dominance of the urban, to expose romantic rural myths. The next phase was an attempt to get rid of the categories of "rural" and "urban" altogether, instead pursuing research into specific sectors while ignoring the rural-urban divide (Hoggart, 1990; Cloke, 1996, p. 435). Bowler (2005, p. 232) is one author who has ignored the binary rural-urban division, recommending instead that rurality be seen as a system with three elements-users of space, used space, use of space, also considering this as a network with various spatial scopes, specifically, the global, the national, and the local. When the scope of the perspective is changed, rural and urban territories are generalised in different ways-rural areas lose before cities in terms of the importance of growth, and so they are unequally represented both in developmental research and in developmental policy.

Another approach involves an attempt to describe a heterogeneous geographic space while avoiding the binary rural-urban division and finding ways of differentiating between spatial categories and identifying their diversity (Halfacree, 1993; Brown and Cromartie, 2004). For exam- 


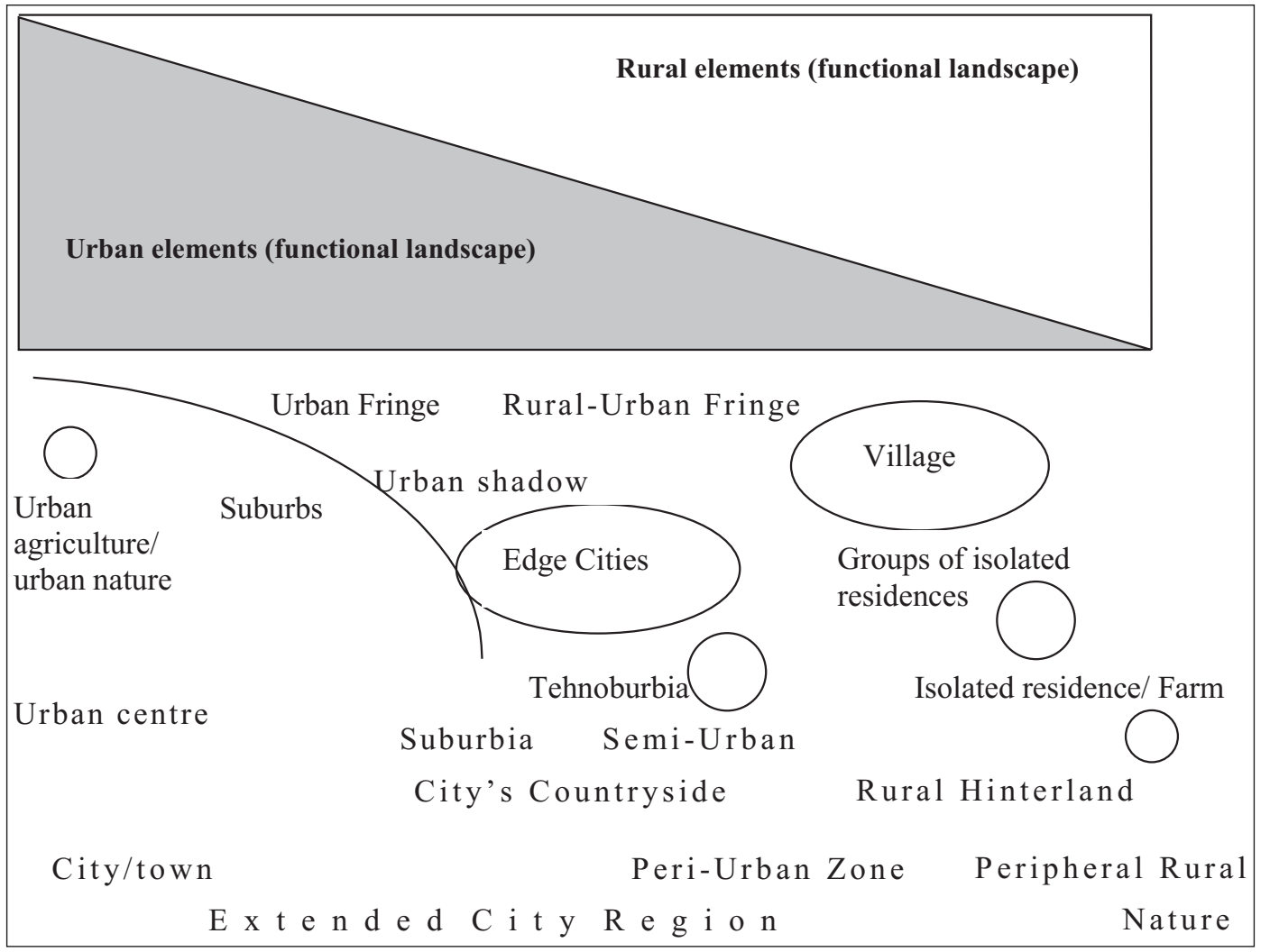

Fig. 1. Urban-rural elements and spatial concepts (modified by the author in accordance with Carr, 1997, p. 138) ple, there can be a focus on specific elements of populated areas, which can create several transitional categories. In Finland four such categories have been described: sparsely populated rural areas, rural core zones, urban-adjacent rural areas, and urban areas (Muilu and Rusanen, 2004). Another approach is to establish rural and urban indices on the basis of many different statistical indicators, thus establishing a complex continuum of statistical indicators to describe the diversity of types of populated areas (Cloke, 1979; Harrington and O'Donoghue, 1998; Cloke and Johnston, 2005). New technologies have also enabled research that is based on geo-referenced data (Coombes and Raybould, 2001; Hugo et al., 2003; Muilu and Rusanen, 2004).

There have also been studies that are focused in particular on new forms of urbanisation emerging in territories between cities and rural areas. These have mixed fragmentary patterns and, often, conflicting type of land use (Antrop, 2000; Gallent et al., 2004). The rural-urban fringe is not just a geographic area within a metropolitan region. It is also a step in the development hierarchy between rural areas and a central city (Carr, 1997; Hart, 1998, p. 10). Lee (1979) has argued that changes in land use in border territories between rural and urban areas depend on the type and initiative of the developer and the issues that control development. Also of importance is the accessibility of the location and of public transportation, as well as the physical nature of the relevant plot of land. These are territories in which rural areas change "as the result of competing combinations of political, economic, social and cultural relations" (Goodwin et al., 1995, p. 1256).

\section{SOCIAL PRODUCTION IN URBAN AND RURAL AREAS}

Research into populated areas is grouped into studies which are conducted without analysis of the concepts of "urbanity" and "rurality" or how these concepts are emerged. In such studies, the concepts are seen as being fixed and universally accepted. Focus is then on other aspects of research-the integration of social groups, the presence of species, environmental pollution, etc. Such research is known as discourse constituted research. At the other end of this continuum of dialectic relations are studies of entire systems of beliefs as to what "rurality" and "urbanity"- ones focused not on the substance as such, but rather on the way in which the substance is represented in social terms. "Rurality" and "urbanity" become fluid and blurred concepts, totally dependent upon context and how it is produced and reproduced through social action (Haugen and Lysgard, 2006, p. 176). These are known as studies in which discourse constitutes society. Another view of such discourses as statistical discourses involves a study of interaction between human agency and social structures in a changing world (Tjallingii, 2000, p. 104). There are many different lifestyles in the contemporary world, with active interaction among social groups and territories (Cloke, 1996; Haugen and Lysgard, 2006). Information about urban and rural residents is not precise if it is only registered in accordance with formal territorial divisions. The rural environment is changing more and more via diversification, rural tourism and commercialisation of the rural landscapethese are just some of the processes that can be observed. In places where the supposed border areas of rural and urban 
areas connect, there tends to be a particularly large diversity among residents and their activities. People living in suburban areas and in urbanised rural areas take part in activities typical both of rural and of urban areas. Social roles and economic activities are periodically changed from the daily, weekly or seasonal perspective. There is no single representation of urbanity or rurality; different social groups will perceive these concepts and make use of them differently, and each will have a different ideal image and possible goal toward which the relevant territory should move in pursuit of its own development (Pahl, 1966; Halfacree, 1993; 2004). Bowler suggests that rural territories be reviewed from the functionalist approach-linking them to economic and political forces, including global ones, which affect them but are not part of them. Also possible is the social representation approach, which is represented through the discourses of different social groups (Bowler, 2005, pp. 231-232).

A common approach for evaluating agents and social structures in rural and urban areas constructs such structures and agrees on them (Jones, 1995; Halfacree, 2004; Ryan, 2006). This happens in various manifestations of space-empirical, literary, ideological, and imagined (Lefebvre, 1974; 1991, p. 3). The triad of Lefebvre's conceptual space includes: 1) spatial practice, which involves particular locations and social formations; 2) representation of space, linked to knowledge, signs and codes; and 3) representational spaces which are embodied in complex symbolic systems and have to do with social life and art. When this theory of a unified space is applied to the concept of rurality and urbanity, one can differentiate between: 1) the "empirical (observed) rural and urban areas" which are characterised by a specific geographic location and set of residents in a specific period of time, also looking at the socioeconomic processes which are involved; 2) the "mental (abstract) rural and urban", as defined in various normative documents and scientific literature, sometimes calculated on the basis of indicators and indices; and 3) the "symbolic (ideal) rural and urban", which utilises such complex symbols as "the idyllic countryside" or "the image or brand of the city", as created in literature, the arts and the mass media (Phillips et al., 2001)—symbols that have become socially important images.

Sometimes the ways in which social space is reflected are combined. Abstract or symbolic characteristics, for example, can be attributed to a specific geographic location. This creates a gap between reality and imagination (Halfacree, 1993; 2004). The symbols of rural and urban areas are separate from real locations, from actual and ordinary landscapes. They become location-based myths which are "free-floating signifiers", and they can attach meaning and character to any other location that has a need for its own identity. This means that identity expands beyond the ordinary landscape in which experience can be gained as to how location-based myths or their symbols have emerged (Halfacree, 1993; Bunce 1994; Hopkins, 1994). Researchers believe that even in those situations in which urban and rural territories are hard to define, and it is difficult to draw boundaries between them, they are nevertheless sufficiently different to have their own location-based identities (Cloke and Park, 1985). If the rural lifestyle and rurality as such are of deep cultural importance and part of a national identity, then this aspect reflects on regional and rural policy and science, as well as on everyday decision-making. That is the case, for example, in Norway (Haugen and Lysgard, 2006).

\section{EXAMPLE: RURALITY AND URBANITY IN RE- SEARCH ON LATVIA}

In the Baltic States, rural territories and their residents have always had special status. The leaders of the 19th century national independence movement grew up there. The changes that took place in rural territories in the 1990s are seen as driving engines for economic restructuring at the conclusion of the Soviet period. Those who implemented change were particularly influenced and motivated by the image of a small and ambitious farmer who obtained his land because of agrarian reforms in Latvia in the 1920s (Lieven, 1993; Taff, 2005; Schwartz, 2005, 2006, 2007). The agricultural community and perceptions about farming are deeply embedded in the national identity of the Baltic States (Unwin, 1998, 1999; Granberg, 1999) and they were romanticised even further under the complicated political and socioeconomic conditions of the Soviet period, thus becoming a particular source of nostalgia for nationalist movements. The concept of rurality, therefore, is both at the centre of the national identity and linked to agricultural production that is fundamentally based on individual family farms. For both rural and urban inhabitants the countryside is perceived as an important aspect of Latvia and a contributor to the sense of identity (Bell et al., 2007, p. 360). Research has proved that Latvian inhabitants "perceive the notion of "countryside" as a bipartite whole and as an opposite concept to the urban environment" that is "characterised by their own family and personal background and experience" where positive emotions are "related to open human relationships, family history, unpolluted nature, peace and quiet, diverse landscape" (Bell et al., 2007, p. 349). Changes in rural territories are usually received negatively_drainage and levelling of the land or disappearance of traditional landscapes and "the farmer was alienated from the land" (Melluma, 1994, p. 61) and, recently, the results of land abandonment (Bell et al., 2007). There have also been efforts, however, to change the view that the countryside is a place dominated by agriculture, and this is a process that began with industrialisation of rural areas and urbanisation of rural centres in the late Soviet period. Today it is continuing and is known as diversification of rural development (Herslund, 2007). The shift from the agriculture discourse to the rural development discourse has occurred very much on the surface in Latvia, without any in-depth research or debate. Despite the fact that there was overproduction of agricultural produce in Europe in the 1990s and there was a shift toward post-productive rural areas, Schwartz (2006) believes that "Latvians feared for the fate of the 'nation of farmers' and its agrarian ethnoscape." 
Studies focused on rural and urban territories in Latvia generally do not dispute their traditional classification or the importance of the territories. The Latvian Geographic Society, for example, has published Folia Geographica, in which that is absolutely true. Cities are considered in their administrative, not their functional boundaries (Krišjāne, 2001; Āboliṇa and Zīlāns, 2002; Donis, 2003; Hazans, 2004; Rozìte and Priedāja-Klepere, 2004). In the classification of urban and rural areas, indicators are compared with respect to such issues as population demography and mobility at the national and the district level (Eglite, 2000; Bauls and Krišjāne, 2000), indicators describing the development of towns and cities at the local government level (Škininkis and Stankeviča, 1999; Krišjāne, 2001), or the statistical territorial unit from the perspective of the formal boundaries of the city of Rìga (Francis, 2002). Without evaluating the concept of rurality or the formal boundaries of rural areas, Latvian researchers see changes in the spatial subcategories of rural territories over a longer period of time-population numbers, changes in forested and agricultural territories in various places, etc. (Penēze et al., 2004; Nikodemus et al., 2005; Bell et al., 2007).

The concept of rurality embodies a "powerful historical element" (Halfacree, 2004), and in Latvia, rurality can be viewed from various aspects of the past. First of all, rurality is part of the identity of Latvia and particularly of the educated middle class of Latvians (Schwartz, 2006). In this discourse, particularly in terms of an idealistic view of rural areas, people see links with sustainable and integrated understanding of environmental protection and agriculture, seeking the oldest aspects of these in the meta-narrative of folklore, the classical Latvian literature of the 19th century, the culture of rural people, the rural landscape, natural and geographic features, symbols and their related associations. This represents Latvian national identity based on rural and natural symbolism (Bunkše, 1992; Bunkše, 1999, p. 124; Bunkše, 2001). One of the most important icons is the farm. The agricultural landscape in interwar Latvia "had many different patterns in its local manifestations, and its image has been preserved in literature, paintings, memories and tales, [and] past memories influence today's ideas about landscapes as well as evaluations of the processes operating within them (Melluma, 1994, p. 61). Bunkše (1992, p. 204) believes that "the attitudes of ancient rural Latvians continue to inform modern Latvian landscape tastes and perceptions of nature. This is true not only of rural folk, but most urbanites, as well." In academic research and in national policy documents, the preservation of the rural population system is seen as a goal, with less focus on the process of change, the driving forces behind the processes, or any evaluation of the same. Idealising a population structure of single family farms means that growth of cities and large villages is seen as a negative process.

Secondly, rurality can be seen as a contrast to urbanity. In Latvia's cities, and particularly in Rìga, local and external forces-cultural impulses from Western Europe and Latvia's neighbouring countries in the Baltic Sea region-have for many centuries been creating a unique urban landscape and traditions (Bunkše, 1979, p. 381; Grava, 1993; Kolbe, 2007). Only Rịga's tourism marketing slogan is based on the urban qualities while other large Latvian cities build their tourism image on nature qualities (Rozìte and Priedāja-Klepere, 2004). The city's development is seen separately from its surrounding district, except Grava who mentions the successful Soviet greenbelt program implemented outside city borders. Another way of looking at this is to see the way in which cities and rural areas have influenced each other as part of development-in terms of an exchange of knowledge, finances, services, goods and other resources. Melluma (1994) and Krišjāne (2001) emphasises Rìga's dominant role. For farms, contacts with Rìga tend to me more important than contacts with small and mediumsized cities that are nearby. The distance from the capital is considered as an important variable to explain disparities in the social and economical development.

Rural discourse in Latvia includes the concept of recreation largely in the context of the Riga agglomeration-this is where many summer homes and colonies of family gardens are found (Melluma, 1994; Grava, 1993; Bunkše, 1999). There has not been a sufficient examination of how important in the recreation of urban residents is the countryside as a whole, not just forests (Donis, 2003, p. 133). From the perspective of food and recreation, the rural-urban relationship discourse might do better in covering the heterogeneous and multinational Latvian population. Social issues are considered in the context of those who are able to promote change in the rural environment (Tisenkopfs, 1999, p. 427): "Post-socialist rurality in itself is a creative field where different actors compete and interact with each other." There must be new rules of the game, and new actors must be created. That means that the values of all who are involved in this are of importance. There is a lack of research in Latvia as to attitudes of different social groups hold toward differences between rural and urban areas.

Third, rurality can be reviewed from the perspective of Soviet ideology, experiences dating back to that time, and the way in which these affect contemporary discourse about rurality (Tisenkopfs, 1999). Beginning in the 1960s, Soviet ideology insisted that rural-urban differences must be liquidated, and planned "rural urbanisation" was the chosen policy and local spatial identity was denied. At the same time, the Soviet tradition was to draw a line between cities and rural areas administratively, which meant that the division was often also a part of research (Apsītis, 2000). Semidetached and detached single family homes were built very rarely under this process, and large apartment buildings were instead put up to create a clearly visible boundary in space (Tammaru, 2001) although ignoring boundaries of traditional rural territories. Of importance also was promotion of urban values and lifestyles, as were efforts to keep urban and rural residents apart. It has to be said, however, that an important role in the Soviet period was assigned to regional planning. It was a centralised and undemocratic process, but it was based on research in such areas as eco- 
nomic issues, back-and-forth migration, recreation and other interactions between rural and urban areas. The concept of rurality as part of Soviet ideology and its later transformation (Shubin, 2006) may offer an additional view of the governing discourses. For example, Swain argues that the socialist countryside in the concluding phase of the Soviet era can be seen as a modern space for mass production, which "ignored" the "late-modern" era of ex-urban incomers and tourists (Swain, 1999).

\section{DISCUSSION AND CONCLUDING REMARKS}

Despite the fact that an in-depth understanding of rurality and urbanity can only be understood in its complexity, the fact that public governance and social groups are divided and fragmented, in part because of the academic world, it is true that each scientific discipline and the researchers who are institutionally embedded therein wish to come up with their own explanation of the concept and their own discourse (Hidding et al., 2000; Hidding and Teunissen, 2002). Generally speaking, researchers admit that there is no single or universal definition of rurality and urbanity, recommending the use of definitions and indicators that are in line with the specific research goals. In each case, the definitions or approaches that have been used should be noted, so that comparative research can be conducted in the future irrespective of the differences and changes of geographic locations (Hahs and McDonnell, 2006). Definitions and criteria must become instruments of research adapted to each of the various aspects of urbanism or rurality (Halfacree, 1993; Harrington and O'Donoghue, 1998). Rural and urban areas are multidimensional and must be viewed in contextual terms-each society in each of its production types creates its own space and the way in which this is embodied between town and country (Lefebvre, 1991, pp. 31-32). One must avoid a linear model of population systems, where cities are goals and rural areas are residual areas (Wilson, 2001; Halfacree, 2004) which are left over in the space that has been occupied by urban areas. They are, however, of value in and of themselves, especially from the perspective of locality. One can speak of the hybrid "urban-rural" or of intermediate spaces, but these must be seen apart from the issue of environmental protection or the developmentalist assumption (Paine, 1978; Tacoli, 1998; Lynch, 2004; Bowler, 2005).

Despite the challenges posed by the dichotomy of urbanity and rurality and the fact that rural and urban areas are becoming increasingly multidimensional while interaction between them is becoming more and more intensive (Campbell, 2003; Dwyer and Childs, 2004), researchers have suggested that the conceptual concepts of "urbanity" and "rurality" are abstractions and metaphors that are needed to evaluate specific places and spaces, to ensure human communication or contextualisation, which enables the bridging of knowledge from one area of science or politics to another (Basten, 2004, p. 93; Tress et al., 2001). The natural and social sciences are no exception to this and it is particularly relevant for interdisciplinary research such as spatial and environmental studies. Future research must focus on the issue of where the boundary between rural and urban areas is found on the urba-rural continuum, particularly taking into account new life styles emerging and new types and forms of human settlements that are developing. This kind of research is necessary in Latvia, focusing on the diverse historical and new settlement forms apart from existing and formal classifications. That is because this depends on overall socioeconomic, historical or geographic context and on the scope of statistical units, and it has been recognised that there has been insufficient research in this area when it comes to countries which have a transitional economy (Thorns, 2002).

\section{ACKNOWLEDGEMENTS}

This paper was prepared with the support of the European Social Fund's National Programme "Support for Doctoral Programmes of Study and Post-Doctoral Research”.

\section{REFERENCES}

Āboliņa, K., Zīlāns, A. (2002). Evaluation of urban sustainability in specific sectors in Latvia. Environ. Devel. Sustain., 4, 299-314.

Aitken, S. C. (1990). Local Evaluations of Neighborhood Change. Ann. Assoc. Amer. Geogr., 80(2), 247-267.

Andranovich, G.D., Riposa, G. (1993). Doing Urban Research. Newbury Park: Sage. 107 pp.

Anonymous (1994). Creating Rural Indicator - for Shaping Territorial Policy. Paris: OECD.

Antrop, M. (2000). Changing Patterns in the Urbanized Countryside of Western Europe. Landsc. Ecol., 15, pp. 257-270.

Apsītis, V. (2000). Latvijas arhitektūra astoṇdesmit gados (1920-2000) [Eighty Years of Latvian Architecture (1920-2000)]. LZA Vēstis, Section A, 54(1/2), 82-89. (in Latvian).

Basten, L. (2004). Perceptions of urban space in the periphery: Potsdam's Kirchsteigfeld. Tijdschrift voor Economische en Sociale Geografie, 95(1), 89-99.

Bauls, A., Krišjāne, Z. (2000). Latvian population mobility in the transition period. Folia Geographica, 8, 24-35.

Bell, S., Penēze, Z., Nikodemus, O., Montarzino, A., Grīne, I. (2007). The Value of the Latvian rural landscape. In Roca, Z., Spek, T., Terknelli, T., Plieninger, T., Höchtl, F. (eds.), European Landscapes and Lifestyles: The Mediterranean and Beyond (pp. 347-362). Lisbon: Ediēões Universitįris Lusófonas.

Bowler, I. (2005). Rural alternatives. In Daniels, P. (ed.), An Introduction to Human Geography: Issues for the 21st Century (pp. 230-245). Harlow: Prentice Hall.

Brown, L., Cromartie J.B. (2004). The Nature of Rurality in Postindustrial Society. In Champion, T., Graeme, H. (eds.), New Forms of Urbanization: Beyond the Urban-Rural Dichotomy (pp. 269-283). Aldershot: Ashgate.

Bryant, C.R., Russwurm, L.H., McLellan, A.G. (1982). The City's Countryside: Land and its Management in the Rural-Urban Fringe. London: Longman, $249 \mathrm{pp}$.

Bunce, M. (1994). The Countryside Ideal: Anglo-American Images of Landscape. London: Routledge. 232 pp.

Bunkše, E.V. (1979). The role of humane environment in Soviet urban planning. Geogr. Rev., 69(4), 379-394.

Bunkše, E.V. (1992). God, Thine Earth is burning: Nature attitudes and the Latvian drive for independence, GeoJournal, 26(2), 203-209. 
Bunkše, E.V. (1999). Reality of rural landscape symbolism in the formation of a post-Soviet, postmodern Latvian identity. Norsk Geografisk Tidsskrift, 53, 121-138.

Bunkše, E.V. (2001). The case of the missing sublime in Latvian landscape aesthetics and ethics. Ethics Place Environ., 4(3), 235-246.

Campbell, H. (2003). Planning for the countryside in the 21st century (but which and whose countryside?). Plan. Theory Pract., 4(1), 75-76.

Carr, M. (1997). New Patterns: Process and Change in Human Geography. Walton-on-Thames: Nelson. 525 pp.

Champion, T., Hugo, G. (2004). Introduction: Moving beyond the urban-rural dichotomy. In Champion, T., Graeme, H. (eds.), New Forms of Urbanization: Beyond the Urban-Rural Dichotomy (pp. 3-24). Aldershot: Ashgate.

Claval, P. (2007). The nature of cities and the analysis of their cultural problems. Tijdschrift voor Economische en Sociale Geografie, 98(2), 153-164.

Cloke, P. (1996). Rural life-styles: Material opportunity, cultural experience, and how theory can undermine policy. Econ. Geogr., 72(4), 433-449.

Cloke, P. J. (1979). Key Settlements in Rural Areas. London: Methuen. $259 \mathrm{pp}$.

Cloke, P. J., Park, C.C. (1985). Rural Resource Management. London: Croom Helm. 473 pp.

Cloke, P., Johnston, R. (2005). Deconstructing human geography's binaries. In Cloke, P., Johnston, R. (eds.), Spaces of Geographical Thought: Deconstructing Human Geography's Binaries (pp. 1-41). London: Sage Publications,

Coombes, M., Raybould, S. (2001). Public policy and population distribution: Developing appropriate indicators of settlement patterns. Environ. Plan. C: Government and Policy, 19, 223-248.

Donis, J. (2003). Designating a greenbelt around the city of Riga, Latvia. Urban Forestry Urban Greenery, 2, 31-39.

Dwyer, J. F., Childs, G. M. (2004). Movement of people across the landscape: A blurring of distinctions between areas, interests, and issues affecting natural resource management. Landsc. Urban Plan., 69, 153-164.

Eglite, P. (2000). The dynamics of Latvia's urban and rural population at the end of the 20th century. Folia Geographica, 8, 36-46.

Francis, I. (2002). Iedzīvotāju un strādājošo teritoriālā izvietojuma īpatnības Rīgā [Location of population and employment in Riga]. Folia Geographica, 10, 90-106.

Funnell, D. C. (1988). Urban-Rural linkages: Research themes and directions. Geogr. Ann., Series B: Human Geography, 70(2), 267-274.

Gallent, N, Shoard, M., Andersson, J., Oades, R., Tudor, C. (2004). England's urban fringes: Multi-functionality and planning. Local Environ., 9(3), 217-233.

Goodwin, M., Cloke, P., Milbourne P. (1995). Regulation theory and rural research: Theorising contemporary rural change. Environ. Plan. A, 27, $1245-1260$

Granberg, L. (1999). Introduction. Rurality in Northern Europe. Sociol. Rur., 39(3), 277-279.

Grava, S. (1993). The urban heritage of the Soviet regime: The case of Riga, Latvia. J. Amer. Plan. Assoc., 59(1), 9-30.

Hahs, A.K., McDonnell, M.J. (2006). Selecting independent measures to quantify Melbourne's urban-rural gradient. Landsc. Urban Plan., 78, 435-448.

Halfacree, K. (1993). Locality and social representation: Space, discourse, and alternative definitions of rural. J. Rural Studies, 9(1), 23-37.

Halfacree, K. (2004). Rethinking 'rurality'. In Champion, T., Graeme H. (eds.), New Forms of Urbanization: Beyond the Urban-Rural Dichotomy (pp. 285-304). Aldershot: Ashgate.

Harrington, V., O’Donoghue (1998). Rurality in England and Wales 1991: A replication and extension of the 1981 Rurality Index. Sociologia Ruralis, 38(2), pp. 178-203.
Harrison, C. M., Burgess, J. (1994). Social constructions of nature: a case study of conflicts over the development of Rainham marshes. Transact. Instit. Brit. Geogr., 19, 291-310.

Hart, J.F. (1998). The Rural Landscape. Baltimore: Johns Hopkins University Press. $401 \mathrm{pp}$.

Haugen, M.S., Lysgard, H.K. (2006). Discourses of rurality in a Norwegian context. Norsk Geografisk Tidsskrift, 60, 174-178.

Herslund, L. (2007). Rural diversification in the Baltic countryside: a local perspective. GeoJournal, 70(1), 47-59.

Hidding, M. C., Teunissen (2002). Beyond fragmentation: New concepts for urban-rural development. Landsc. Urban Plan., 58, 297-308.

Hidding, M., Needham, B., Wisserhof, J. (2000). Discourses of town and country. Landsc. Urban Plan., 48, 121-130.

Hidle, K., Cruickshank, J., Nesje, L.M. (2006). Market, commodity, resource, and strength: Logics of Norwegian rurality. Norsk Geografisk Tidsskrift, 60, 189-198.

Hill, M. (2003). Rural Settlement and Urban Impact on the Countryside. London: Hodder and Stoughton. 128 pp.

Hoggart, K. (1990). Lets do away with rural. J. Rural Studies, 6, 245-257.

Hopkins, J. (1998). Signs of the post-rural: Marketing myths of a symbolic countryside. Geografiska Annaler B, 80(2), 65-81.

Hugo, G., Champion, A., Lattes, A. (2003). Towards a new conceptualization of settlements for demography. Popul. Develop. Rev., 29(2), 277-297.

Jones, G.A. (2004). Bridging the rural-urban divide: What can the urban learn from the rural? Reflections on the case of Mexico. In Hamza, M. (ed.), From Welfare to Market Economy: Policy Shifts in Urban Development (pp. 123-145). London: Earthscan Publication.

Jones, O. (1995). Lay discourses of the rural: Developments and implications for rural studies. J. Rural Studies, 11(1), 35-49.

Kolbe, L. (2007). Central and Eastern European capital cities: Interpreting www-pages-History, symbols and identity. Planning Perspectives, 22, 79-111.

Krišjāne, Z. (2001). Jaunas iezīmes Latvijas mazo pilsētu attīstībā [New trends in the development of small towns of Latvia]. Folia Geographica, IX, 33-41.

Lacour, C., Puissant, S. (2007). Re-urbanity: Urbanising the rural and ruralising the urban. Environ. Plan. A, 39, 728-747.

Lee, L. (1979). Factors affecting land-use change at urban-rural fringe. Growth and Change, 10(4), 25-31.

Lefebvre, H. (1991). The Production of Space. Oxford: Blackwell, 454 pp.

Lieven, A. (1993). The Baltic Revolution. New Haven: Yale University Press. $454 \mathrm{pp}$.

Lynch, K. (2004). Rural-Urban Interaction in the Developing World. London: Routledge. 209 pp.

Mann, P.H. (1965). An Approach to Urban Sociology. London: Routledge and Kegan Paul. 232 pp.

McDonnell, M.J., Pickett, S.T.A. (1990). Ecosystem structure and function along urban-rural gradients: An unexploited opportunity for ecology. Ecology, 71(4), 1232-1237.

Melluma, A. (1994). Metamorphoses of Latvian landscapes during fifty years of Soviet rule. GeoJournal, 33(1), 55-62.

Muilu, T., Rusanen, J. (2004). Changes in population and industries in the rural areas of Finland: From analysis of administrative regions to GIS based approach. In Banski, J. (ed.), Changing Functions of Rural Areas in the Baltic Sea Region (pp. 109-117). Warsaw: Institute of Agricultural and Food Economics and Institute of Geography and Spatial Organization.

Nikodemus, O., Bell, S. Grīne, I., Liepiņš I. (2005). The impact of economic, social and political factors on the landscape structure of the Vidzeme Uplands in Latvia. Landscape and Urban Planning, 70, 57-67.

Pahl, R.E. (1966). The rural-urban continuum. Sociologia Ruralis, 6, 299-329. 
Paine, S. (1978). Some reflections on the presence of 'rural' or of 'urban bias' in China's development policies 1949-1976. World Development, 6, 693-707.

Penēze, Z., Nikodemus, O., Grīne, I., Rasa, I., Bell, S. (2004). Local changes in the landscape structure of Kurzeme during the 20th century. Folia Geographica, 12, 56-64.

Pfuderer, S. (2003). Rural Development Statistics in Selected ECE Countries. UNECE. Retrieved 10.02.2008, www.unece.org/stats/documents/ces/ac.61/2003/21.e.pdf

Phillips, M., Fish R., Agg, J. (2001). Putting together ruralities: Towards a symbolic analysis of rurality in the British mass media. J. Rural Studies, 17, 1-27.

Plowden, B. (1995). Measuring the Unmeasurable: Twenty Indicators for the Countryside. CPRE. London: Council for the Protection of Rural England

Pumain, D., Saint-Julien, T., Cattan, N., Rozenblat, C. (1992). The Statistical Concept of the Town in Europe. Luxemburg: EUROSTAT. 91 pp.

Richardson, T. (2000). Discourses of rurality in EU spatial policy: The European spatial development perspective. Sociologia Ruralis, 40(1), 53-71.

Rozīte, M., Priedāja-Klepere, L. (2004). The Importance of Latvia's Cities in Tourism. Folia Geographica, 12, 74-83.

Ryan R.L. (2006). Comparing the attitudes of local residents, planners, and developers about preserving rural character in New England. Landsc. Urban Plan., 75(1-2), 5-22.

Schwartz, K.Z.S. (2005). Wild horses in a „European Wilderness”: Imagining sustainable development in the post-Soviet countryside. Cult. Geogr., 12, 292-320.

Schwartz, K.Z.S. (2007). „The occupation of beauty”: Imagining nature and nation in Latvia. East Eur. Polit. Soc., 21(2), 259-293.

Schwartz, K.Z.S. (2006). „Masters in our native place”: The politics of Latvian National Parks on the road from communism to „Europe”. Polit. Geogr., 25, 42-71.

Shubin, S. (2006). The changing nature of rurality and rural studies in Russia. J. Rural Studies, 22(4), 422-440.

Simmons, C. S., Sorrensen, C., Walker, R. (2002). Urban rural linkages and environmental change: Addressing the human dynamics of urban ecologies. Urban Ecosyst., 6, 5-8.

Škinịisis, P., Stankeviča V. (1999). Latvijas pilsētu sociāli ǵeogrāfiskās atškirības [Social structural differences of urban areas in Latvia]. Folia Geographica, 7, 94-115.
Sorokin, P.A., Zimmerman, C.C. (1929). Principles of Rural-Urban Sociology. New York: Holt. 652 pp.

Swain, N. (2000). The Rural Transition in Post-Socialist Central Europe and the Balkans. Halle: Max Planck Institute for Social Antropology. 26 pp.

Tacoli C. (1998). Rural-urban interactions: a guide to the literature. Environ. Urbaniz., 10 (1), 147-166.

Taff, G. (2005). Conflict between global and local land-use values in Latvia's Gauja National Park. Landsc. Res., 30(3), 415-430.

Tammaru, T. (2001). Suburban growth and suburbanization under central planning: The case of Soviet Estonia. Urban Studies, 38(8), 1341-1357.

Theobald D.M. (2004). Placing exurban land-use change in a human modification framework. Frontiers Ecol. Environ., 2(3), 139-144.

Thorns, D.C. (2002). The Transformation of Cities: Urban Theory and Urban Life. New York: Palgrave Macmillan. 258 pp.

Tilt, J.H., Kearney, A.R., Bradley, G. (2007). Understanding rural character: Cognitive and visual perceptions, Landsc. Urban Plan., 81, 14-26.

Tisenkopfs, T. (1999). Rurality as a created field: Towards an integrated rural development in Latvia? Sociologia Ruralis, 39(3), 411-430.

Tjallingii, S.P. (2000). Ecology on the edge: Landscape and ecology between town and country. Landsc. Urban Plan., 48, 103-119.

Tonnies, F. (1889, 2001). Gemeinschaft und Gesellschaft. In Harris, J. (ed.), Community and Civil Society (pp. 3-246). Cambridge: Cambridge University Press.

Unwin, T. (1998). Rurality and construction of the nation in Estonia. In Picles, J., Smith, A. (eds.), Theorizing Transition: The Political Economy of Post-Communist Transformations (pp. 284-306). London: Routledge.

Tress, B., Tress, G., Decamps, H., d'Hauteserre, A.-M. (2001). Editorial: Bridging human and natural sciences in landscape research. Landsc. Urban Plan., 57, 137-141.

Tuan, Y.-F. (1978). The city: Its distance from nature. Geogr. Rev., 68(1), $1-12$.

Unwin, T. (1999). Contested reconstruction of national identities in Eastern Europe: Landscape implications. Norsk Geografisk Tidsskrift, 53, 113-120.

Wilson, G.A. (2001). From productivism to post-productivism....and back again? Exploring the (un)changed natural and mental landscapes of European agriculture. Transact. Instit. Brit. Geogr., 26(1), 77-102.

Wirth, L. (1938). Urbanism as way of life. Amer. J. Sociol., 44(1), 1-24.

Received 14 May 2008

\section{LAUKU UN PILSĒTAS KONCEPTI KĀ ANALĪTISKAS KATEGORIJAS DAUDZDIMENSIONĀLIEM PĒTĪJUMIEM}

Raksts ir pārskats par lauku un pilsētu konceptiem, dažāāām pieejām lauku un pilsētu atšķirību noteikšanā. Pētījums ir aktuāls gan Latvijas, gan plašākā mērogā, jo sabiedrības attīstība veicina lauku un pilsētas identitāšu izmaiṇas, tāpat arī vietējo un reğionālo pašvaldību reformas gan Latvijā, gan citur mudina pārskatīt lauku un pilsētas konceptus un izprast, cik nozīmīgi tie ir ne tikai iedzīvotājiem un pārvaldei, bet arī pētniecībā - jo sevišḳi tajā, kas pēta telpiskās atšķirības un dabas un cilvēku attiecības, piemēram, vides un ǵeogrāfijas zinātnē. Par spīti tam, ka dziḷāka lauku un pilsētas izpratne ir tikai tās kompleksumā, fragmentētās sabiedrības iespaidā katrai no zinātnes disciplīnām ir vēlme veidot savus konceptu skaidrojumus un diskursus. Rakstā apskatīts lauku un pilsētu kontinuums un dihotomija, lauku un pilsētu robežas noteikšanas problēmas. Minētas un novērtētas vairākas pieejas, kā pētīt ruralitāti un urbanitāti, kuras ietilpst divās pamatgrupās aprakstošās (balstās uz empīriskiem datiem) un sociālās (balstās dažādiem telpas uztveres veidiem). Autore pievienojas pētniekiem, kuri atzīst, ka nepastāv viena universāla ruralitātes un urbanitātes definīcija. Tie ir daudzdimensionāli un mijiedarbībā esoši koncepti, kas jāskata kontekstuāli, t.i., atkarībā no vispārējā sociāli ekonomiskā, vēsturiskā vai ǵeogrāfiskā konteksta un statistisko vienību mēroga. Pilsētu un lauku definīcijas un indikatori jālieto atbilstoši konkrētiem uzdevumiem, un tiem ir jākḷūst par pētniecības instrumentiem. Vienlaikus „pilsēta” un „lauki” kā abstrakcijas un metaforas izmantojami cilvēku komunikācijai, dodot iespējas zināšanu pārnesei, tai skaitā starp dabas un sociālajām zinātnēm. Raksta noslēgumā apskatīts, kā „lauki” un „pilsētas” tiek atspoguḷoti pētījumos par Latviju - prevalē lauku kā nacionālās identitātes diskurss un lauku-pilsētu teritoriju izvērtējums administratīvo robežu ietvaros. Autore rosina, ka turpmākajiem pētījumiem, jo seviški ǵeogrāfijā un vides zinātnēs, būtu vairāk jāpievēršas robežškirtnei starp laukiem un pilsētām, ṇemot vērā iedzīvotāju dzīves veida izmainas un jaunās apdzīvojuma formas. 